\title{
A Message to IUGS National Members
}

There is an obvious need in many parts of the world to strengthen the geological sciences to address specific mational and international problems. One way to do this would be through the national members of the International Union of Geological Sciences, who make up the backbone of the Union. These "adhering" organizations are "designated by the appropriate authority," according to the IUGS Constitution, to represent the geological scientists of that country. They now range from geological survey departments to academies of science, scientific councils, geological societies, universities and national committees of geology. It is their representatives who make up the voting membership of the IUGS Council, the governing body of the Union.

IUGS intends to become more active in facilitating the establishment and operation of its adhering members for several reasons. First, there is a need to provide a national focus for all geological activities in countries where no suitable mechanism, such as a national geological society, now exists. Second, stronger links are needed between national and international geoscience communities, and national members may be able to fulfill this function, reporting annually on their accomplishments. Third, national members can provide support and advice to IUGS on its activities, including those under the International Geological Correlation Programme and the International Lithosphere Program. Last, national members can be a source of recommendations for new initiatives to be undertiken by IU GS.

At the latest meeting of the IUGS Executive Committee, discussion on this important matter was led by Prof. Umberto Cordani (Brazil), following a review of national activities in South America. The result was a resolution that IUGS take action to stimulate existing national members and to foster the establishment of new ones in countries where they do not now exist, recommending activities that might be incorporated in any terms of reference to be adopted. The goal would be to stimulate national geological activities and to increase the feedback to the Union.

To do this there needs to be a more thoughtful interaction among representatives of national members as a basis for stronger and more concerted international action. Opportunities do exist for the IUGS Council to meet during sessions of the International Geological Congress, but unfortunately these can deal only with the most pressing administrative matters in hurried meetings squeezed between scientific sessions and social functions. This may not be the most effective way of drawing on our collective talents and giving due consideration to the conduct of our science.

The same point has been raised in a review conducted by Prof. R. Trümpy of relations between IUGS and the Congress. One solution would be for the Council to convene mid-term meetings, normally two years after each Congress, to focus on policy, program, problems and new opportunities. It seems to me that if we are to draw on our full capabilities, we may then have an opportunity of stimulating and strengthening both national and international geoscience. I will be writing to national members on this important matter soon and would welcome comments from all interested parties.

W.W.Hutchison, President IUGS

\section{FORTHCOMING ARTICLES}

Evolution of a West African Greenstone Belt

Exotic Terranes of South America

Quaternary Sediments of the NW Arabian Gulf

The International Association of Hydrogeologists

Geology and Urban Planning in SE Asia

Rift Valley Volcanics and Mantle Magmas

Digital Image Processing in Argentina
Published in 1986 by Instituto Geologico y Minero de Espana and Empresa Nacional Adaro de Investigaciones Mineras, S.A., Madrid.

449 pages, 37 plates. Price US $\$ 50.00$ (surface mail).

Available shortly from IUGS, Room 177, 601 Booth Street, Ottawa, Canada KIA OE8.

(Copies may also be ordered from ENADIMSA, Serrano 116, Madrid 6, Spain for US $\$ 45$ plus $\$ 5.00$ postage and handling.) 